\title{
Mcl-1 Inhibitor MIK665
}

National Cancer Institute

\section{Source}

National Cancer Institute. Mcl-1 Inhibitor MIK665. NCI Thesaurus. Code C133174.

An inhibitor of induced myeloid leukemia cell differentiation protein ( $\mathrm{Mcl}-1 ; \mathrm{BCl} 2-\mathrm{L}-3)$, with potential pro-apoptotic and antineoplastic activities. Upon administration, MIK665 binds to and inhibits the activity of $\mathrm{Mcl}-1$, which promotes apoptosis of cells overexpressing $\mathrm{Mcl}-1$. Mcl-1, an anti-apoptotic protein belonging to the $\mathrm{Bcl}-2$ family of proteins, is upregulated in cancer cells and promotes tumor cell survival. 